\title{
Participation of citizens in sustainable development of big cities
}

\author{
Sofia Kalyazina $^{1 *}$, Aleksandra Borremans ${ }^{1}$, and Alissa Dubgorn ${ }^{1}$ \\ ${ }^{1}$ Peter the Great St.Petersburg Polytechnic University, Polytechnicheskaya, 29, St. Petersburg, \\ 195251, Russia
}

\begin{abstract}
The modern world is too densely populated, which prevents the lack of energy, the consequences of greenhouse gas emissions, the accumulation of hazardous waste, the use of toxic production methods. Without involving interested citizens, business representatives, and local authorities in solving these problems, it is not possible to solve the emerging problems. The article provides an overview of the existing ways of citizens' participation in solving environmental problems and ensuring sustainable development in large cities. In addition, some examples of real work being done in this direction are considered.
\end{abstract}

\section{Introduction}

The growth of cities is connected with such problems as deterioration of conditions in air and transport, economic risks such as unemployment, lack of resources, energy, infrastructure, health problems of citizens due to environmental disruption, etc.

Not always people who inhabit cities understand that these problems concern them right now, do not understand the scale of problems, they hope for scientists who will find solutions to problems and do not consider their participation in solving problems. This means that it is necessary to attract people's attention to the problems of urban growth, to show people the benefits of participating in solving problems. It is desirable to find technologies that are understandable to everyone, easy to use for everyone, interesting to people who will show everyone their contribution to solving global problems. Sustainable development requires methods and tools to measure and compare the environmental impacts of human activities for various products [1].

\section{Literature Review}

Nowadays the concept of Smart city is developing. It's strategic principles aligning to the three main dimensions (technology, people, and institutions) of smart city: integration of infrastructures and technology-mediated services, social learning for strengthening human infrastructure, and governance for institutional improvement and citizen engagement According to the United Nations Population Fund (www.unfpa.org) by 2030 the number of

\footnotetext{
*Corresponding author: alyovina@gmail.com
} 
people living in urban areas is expected to increase to 5 billion. With the rapid increase of the urban population worldwide, cities face a variety of risks, concerns, and problems; for example, physical risks such as deteriorating conditions in air and transportation, and economic risks such as unemployment [2]. More often when describing smart cities, they pay attention to technology. Nevertheless, In marketing language, smartness is centered on a user perspective [3]. A smart city is required to adapt to the needs of the user and provide customizable interfaces [4]. Rios's [5] approach define smart city as a city that gives inspiration, shares culture, knowledge, and life, and motivates its inhabitants to create and flourish in their own lives. Creativity is recognized as a key driver to smart city, and thus people, education, learning and knowledge have central importance to smart city. The expansive notion of smart city includes creating a climate suitable for an emerging creative class [6]. This confirms the idea that people's participation in the development and resolution of the problems of large cities is very important. Trained, qualified, trained people will be able to bring new ideas to high-tech industries, without which existing problems can not be solved. There are concepts of "Smart Communities" in which the government, business and residents (from the scale of the district to the national scale) work together to solve problems. In the conditions of the dynamic development of society, management should be in a state of continuous development, which today can not be provided without exploring trends and opportunities, without choosing alternatives and directions for development. Cognitive calculations and their opportunities for creating interaction with citizens open new opportunities for government organizations to improve the lives of citizens and the business environment provide personalized experience and optimize programs and service results.

There is a CBEP concept (Community-Based Environmental Protection), which is designed to maximize the use of scarce resources, encourage local support, and consider the economic well-being of communities (Environmental Protection Agency, EPA). In order for citizens to actively participate in solving environmental problems, they should clearly see the problem, understand alternative ways to solve it, and see a positive effect in the event of a solution to the problem. Citizens are willing to participate in projects that benefit the entire community and do not require understanding of complex technical information [7].

The adopted European Union directive on energy consumption encourages producers to design products in accordance with their environmental impact and energy savings throughout their life cycle. The California Law on Solutions for Global Warming established an official schedule for reducing greenhouse gas emissions. Public and private procurement departments in many countries include requirements for suppliers regarding environmentally preferable procurement. The world's largest corporations - Coca Cola, Sharp, BT - have launched environmental impact assessment programs for the entire life cycle of their products and the environmental assessment of their suppliers. Communication and vendor training is an essential part of any sustainable supply chain initiative.

The United States has adopted the Federal Electronics Challenge (FEC) program, which provides for purchasing more environmentally friendly electronic products (Energy Star or EPEAT), reducing the impact of the products used, and disposing obsolete products in an environmentally sound manner. Many companies undergo voluntary certification under ISO 14000 to demonstrate commitment to "green" policies. The document establishes standards for environmental auditing, labeling and life cycle assessment. Companies report on corporate and social responsibility, disclose information on carbon emissions, provide a healthy environment for workers, use non-toxic materials. It is possible to name such companies as Dell, Hewlett-Packard, IBM, Sun Microsystems, AMD, WalMart.

Itron conducted a global study of the Itron Resourcefulness Index of the utilities sector, which interviewed the opinion of the managers of utilities and their clients from around the world. The overwhelming majority of the respondents said that to improve the efficiency of the industry it is necessary to use innovative technologies, including for the transformation 
of energy supply and water management systems. The introduction of a mechanism for interaction and collection and analysis of data on the consumption of energy and water resources in real time will make it possible to lay a solid foundation for the effective use and conservation of valuable resources. In case of successful implementation, this strategy will allow building intellectual cities, opening up new prospects for effective use of resources. Also, technologies allow people to provide necessary information in real time, helping them make informed decisions to optimize resources and improve the quality of life in the city. At the same time, the final effectiveness of technology implementation depends on how successfully people cooperate with each other, especially in the issues of solving energy, transport problems and urbanization problems [8].

The use of renewable energy sources helps to mitigate the effects of excess $\mathrm{CO}_{2}$ emissions for clean and sustainable development. Involving citizens in the use of solar energy, for example, for drying agricultural products, has a good potential for energy conservation in developing countries. Biodiesel from nonedible vegetable oil. The improved cookstoves provide better kitchen environment for rural women and improve their health standards. At the same time it also reduces fuel collection for them [9]. An important aspect is also the participation of a wide range of people in separate waste collection programs. This helps in increasing the possibility of more complete recycling of waste and allows to generate more energy during processing. The separate collection of garbage depends on the activity and consciousness of the participants in the process at all stages. Separate collection of garbage is under the responsibility of every single citizen of the country. The separation of garbage also requires a certain amount of time and effort to train the inhabitants.

It is obvious that people's participation in the work to meet the needs expressed in the concept of sustainable development is necessary, especially to achieve a balance between socio-economic and environmental aspects [10]. For example, the transition to renewable energy sources benefits both the environment and the welfare and satisfaction of people's needs. At the same time, it is important that the adopted decision also correspond to the interests of the business, that is, the business should be interested in participating in the proposed projects.

The idea of smart specialization of cities and regions is spreading fast and has successfully become a platform for community development. It is interesting to consider the concept of a city through the lens of sustainability particularly on social issues [11].

Projects of intellectual cities affect the quality of life of citizens and are aimed at facilitating the participation of educated and interested citizens in the management of the city. A person should be able to connect to achieve social and cultural capital, and achieve massive economic productivity growth [12]. An environment for human interaction, communication and cultural development with improvements in the quality of life, creates a condition for social sustainability [13]. That is, people's participation in decision-making and their influence on the choice of ways of development is one of the criteria of a sustainable society.

\section{Methodology}

The methodology used in this article is to investigate available materials. Materials for analysis were selected based on the reflections of various disciplines trends related to the Environmental Science, for example, Energy Efficiency, Renewable Energy, Sustainable Development, Urban Environmental Engineering.

The holistic engineering view was used. This approach is typical for complex research tasks, which include the task of introducing technologies in Smart City and integrating into it residents. 


\section{Results}

GreenIT recognizes that for prosperity, a combination of social responsibility, smart use of resources and technological innovation is required. The company is engaged in projects to reduce the energy consumption of data centers. Due to the use of highly efficient cooling technologies, power equipment, virtualization technologies, it is possible to reduce energy consumption of data processing centers by up to $70 \%$.

The Notting Date Urban Studies Center provides special training for adults and students from the primary school level to the college level in the field of urban environment and resource use.

Planning For Real ${ }^{\circledR}$ allows the participation of local volunteers to build 3D models for community planning to take into account the problems and priorities of local residents.

The City of Charlotte (North Carolina, USA) is implementing a unique public-private partnership program aimed at sustainable economic development, which can act as a model for any other aspects of society. To this end, the mayor of the city is developing a program for the conservation of energy and water resources, aimed at reducing operating costs. The main goal of the program is to ensure a balanced development of the city center, provide the necessary information to change behavior and simplify making informed decisions. The key to the success of the program is cooperation. The balanced development of the city center is shared by technology companies, local enterprises, utilities, city government and nongovernmental organizations [8].

In St. Petersburg, the development of the Smart City concept began. The goal of the development of this project is to achieve qualitative changes in the advanced sectors of the economy and in key spheres of life connected with man and the development of human capital - first of all in healthcare, education, social sphere, housing and communal services, transport, improvement and environmental safety. Within the framework of the pilot project, an automated resource accounting system has been installed in a number of city houses. There is a project to develop infrastructure for electric vehicles. The project of software and hardware complex for monitoring and managing resource supply is proposed, which allows to carry out weather regulation of heat energy supply and promptly inform about job failures in the resource supply networks. A prototype of the project for equipping streetlights with a radio-controlled relay is being run, which will be controlled by motorists and pedestrians. This allows to achieve significant energy savings in street lighting.

A group of Peter the Great St.Petersburg Polytechnic University students developed a project to create a walking zone in the center of the city of St. Petersburg equipped with special piezoelectric tiles, which allow to generate electricity for lighting when walking.

Project Objectives:

- Implement the alternative energy sources

- Increase people's responsibility

- Educate the society

Team members:

- $\quad$ Project Manager

- $\quad$ Engineers

- Logistics

- $\quad$ IT specialists

- Designers

The team used the idea of technology applied in the Olympic Park of London, where it showed good efficiency in energy production. At the same time, the task was to adapt the technology to the conditions of operation in St. Petersburg and increase energy efficiency, as well as use of technology for other purposes. Within the framework of this project, it is critical at the earliest stages to attract public attention to the problems, that is, the project 
presupposed an educational and training component to attract public attention to the problem and the ways to solve it.

The table below shows the expected stages of the introduction of technology, the key feature of which is to increase the participation of residents in the implementation of technology in everyday life.

Table 1. Stages of technology implementation.

\begin{tabular}{|c|c|c|}
\hline Stage & Description & Planned result \\
\hline $\begin{array}{c}\text { The creation of a site } \\
\text { in the city center with } \\
\text { a piezoelectric coating } \\
\text { as a "test exhibit" }\end{array}$ & $\begin{array}{c}\text { This stage, in fact, implies the creation } \\
\text { of a science-based "museum" in a } \\
\text { public place. It is necessary to choose } \\
\text { a tourist site and equip it with a } \\
\text { piezoelectric cover, panels for } \\
\text { collecting statistics and various } \\
\text { techniques for photo sharing. }\end{array}$ & $\begin{array}{c}\text { As the results of this stage, it } \\
\text { is primarily assumed that } \\
\text { grabbing public and media } \\
\text { attention to the problem. } \\
\text { Demonstration of simple } \\
\text { solution, which can be } \\
\text { realized in cooperation with } \\
\text { citizens }\end{array}$ \\
$\begin{array}{c}\text { Expanding the } \\
\text { piezoelectric surfaces } \\
\text { in the city center, } \\
\text { collecting energy and } \\
\text { using it for lighting } \\
\text { the monuments at } \\
\text { night }\end{array}$ & $\begin{array}{c}\text { This step would allow to demonstrate } \\
\text { the real advantage of the technology to } \\
\text { municipality and again to citizens and } \\
\text { tourists. This is done due to the } \\
\text { combinations of the demonstration of } \\
\text { how the technology may support } \\
\text { cultural legacy. To do so, each } \\
\text { monument in the city center should be } \\
\text { equipped with the information board } \\
\text { with technology and overall project } \\
\text { description }\end{array}$ & $\begin{array}{c}\text { is planned result for this step } \\
\text { and, potentially, tourists } \\
\text { attention, making the idea } \\
\text { world-wide }\end{array}$ \\
$\begin{array}{c}\text { Implementing into } \\
\text { everyday life, } \\
\text { collaborating with } \\
\text { business and } \\
\text { municipal } \\
\text { stakeholders }\end{array}$ & $\begin{array}{c}\text { technology has now to be implemented } \\
\text { in business and municipality. this step } \\
\text { is based on the contracts making and } \\
\text { business network development to } \\
\text { utilize the technology }\end{array}$ & $\begin{array}{c}\text { The planned result for this } \\
\text { step is a set of business } \\
\text { contracts for using the } \\
\text { technology, investments } \\
\text { analysis and environmental } \\
\text { impact analysis }\end{array}$ \\
\hline
\end{tabular}

As a result of the project, the following will be achieved:

1) A source of alternative energy, adapted for use in a big city

2) People are involved in solving global problems

3) This way of obtaining energy reduces its cost.

The project may be of interest to municipal authorities, transport companies, as it allows to reduce the cost of lighting cities, bus stops, metro stations. Energy can also be used for electric vehicles.

\section{Conclusion}

Problems, including environmental and energy problems arising from accelerated urbanization, the use of inefficient technologies, require urgent solutions. Without attracting the attention of citizens who can influence business and government representatives, it is difficult to solve these problems. As the study showed, there are many examples of projects that are designed for the interest and participation of citizens. Such projects correspond to new trends, such as a smart city, energy-saving technologies, the use of alternative energy 
sources, efficient recycling of garbage. The implementation of such projects corresponds to the provisions of the concept of sustainable development. The more widely such projects are used and the more people will be interested in using them, the sooner humanity will be able to develop without threat to itself.

\section{References}

1. I. Dincer Environmental Issues. I. Energy Utilization. Energy Sources, Part A: Recovery, Utilization, and Environmental Effects 23(1) 69-81 (2001)

2. T. Nam, T. A. Pardo. In Proc. of the 12th Annual Int. Digital Government Research Conf.: Digital Government Innovation in Challenging Times (dg.o '11). ACM, New York, NY, USA, 282-291 (2011)

3. C. Klein, G. Kaefer. In Proc. of the 8th International Conference, NEW2AN and 1st Russian Conf. on Smart Spaces, ruSMART 2008 (St. Petersburg, Russia, 2008)

4. I. Marsa-Maestre, M. A. Lopez-Carmona, J. R. Velasco, A. Navarro. Journal of Networks, 3(5), 30-41 (2008)

5. P. Rios. Creating "the smart city" (2008).

6. A. Boulton, S. D. Brunn, L. Devriendt, Cyberinfrastructures and "smart" world cities: Physical, human, and soft infrastructures. Int. Handbook of Globalization and World Cities. Cheltenham, (U.K.,Edward Elgar, 2008)

7. R. A. Irvin, J. Stansbury. Public Administration Review, 64: 55-65 (2004)

8. URL: https://enterprise.microsoft.com/ru-ru/articles/industries/citynext/the-path-tosmarter-cities/

9. N.L. Panwar, S.C. Kaushik, S. Kothari. Renewable and Sustainable Energy Reviews, 15-3, 1513-1524 (2011)

10. A. Levina, I. Ilin, R. Esedulaev. E3S Web of Conferences. 33, 030092017 (2018)

11. T. Monfaredzadeh, R. Krueger. Procedia Engineering, 118, 1112-1118 (2015)

12. H. Chourabi, T. Nam, S. Walker, J.R. Gil-García, S. Mellouli, K. Nahon, T.A. Pardo, H.J. Scholl, Understanding smart cities: an integrative framework, Proceeding of HICSS, 2289-2297 (2012)

13. M. Polese, R. Stren, The Social Sustainability of Cities: Diversity and the Management of Change. (University of Toronto Press, Toronto 2000) 